\title{
THE CATERPILLARS WHICH EAT THE LEAVES OF SUGAR CANE IN PORTO RICO. ${ }^{1}$
}

By Thos. H. Jones, former Entomologist, and GEorge N. WoLcotT, Entomologist.

Seven species of lepidopterous larvae are known to feed on the leaves of sugar cane in Porto Rico. Four of these, Prenes nero Fabr., Prenes ares Feld, Atrytone vittelius Fabr., and Perichares corydon Fabr., are caterpillars which have the first segment of the body much constricted, giving the appearance of a narrow neck and a large head. The adults of these four species are skipper butterflies of the family Hesperidae.

The other three species are Cirphis (Heliophila) latiuscula H. S., Laphygma frugiperda S. \& A., and Remigia (Mocis) repanda Fabr., the adults of which are moths belonging to the famliy Noctuidae.

With the exception of Prenes nero, the larvae of the skipper butterflies have never been noted to be sufficiently abundant to be important pests of sugar cane in Porto Rico. The caterpillars of two of the noctuid moths, Laphygma frugiperda and Remigia repanda, do at times, however, occur in destructive numbers. This is especially true of Laphygma frugiperda. Although it is heavily parasitized its eggs are laid in large clusters and, if a few clusters in one part of a field are unparasitized, they may produce enough caterpillars to entirely defoliate the cane or malojillo grass before they are destroyed by the larval parasites.

Six of the species of lepidopterous larvae mentioned are discussed on the following pages. The information so far obtained concerning the large skipper, Perichares corydon, the larvae of which occasion-

1 This paper was left by Mr. Jones marked "Not completed" when he resigned in Sep. tember 1914. It was to complete the publications on the more important pests of sugar cane in Porto Rico, of which the others are: (1) Aphids or Plant-Lice attacking Sugar Cane in Porto Rico, Bul. No. 11, (2) The Sugar-Cane Moth Stalk-Borer, Diatraea saccharalis, Bul. No. 12, (3) The Sugar-Cane Weevil Root Borer, Diaprepes spengleri, Bul. No. 14, all by $\mathrm{Mr}$. Jones, and the papers by Mr. E. G. Smyth on the white grubs injuring sugar cane in Porto Rico. It has been finished by the junior author.

Dr. L. O. Howard, Chief of the U. S. Bureau of Entomology, very kindly authorized the use of the cuts illustrating the portion of this article dealing with Laphygma frugiperda, the other drawings 'having been made by' the senior author. To the various specialists in the Bureau of Entomology or in the National Museum who identified specimens, the authors are greatly indebted: to Dr. Harrison G. Dyar, who identified the Lepidoptera, to Dr. J. M. Aldrich or Mr. W. R. Walton, who identified or named and described the Diptera, and to Mr. S. A. Rowher, Dr. C. F. W. Muesebeck, Mr. A. B. Gahan and Mr. A, A. Girault, who determined the Hymenoptera. 
ally feed on cane, is not sufficient to warrant the inclusion of an account concerning it.

Prenes nero Fabr.

Larvae of this skipper have been found feeding upon the leaves

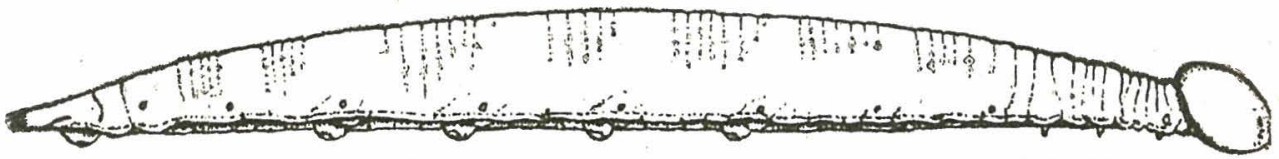

Fig. 10.-Larva of Prenes nero Fabr. Enlarged 2 times. (Original.)

of sugar cane, rice, bamboo, malojillo grass, and Johnson grass. They are more common during the fall and winter months, when a few individuals are often found in fields of young cane.

The eggs are hemispherical, about $1.8 \mathrm{~mm}$. in diameter, and are laid singly on leaves of cane. When first laid they are nearly white, becoming grey with age, often with a rosy tinge, and with the apex and a circle about and just below it darkest. Under a lens, the entire curved surface shows delicate reticulations, hexagonal in shape. The eggs hatch in four or five days into caterpillars about $2 \mathrm{~mm}$. long, light grey except for a large black head, which devour the free portion of the egg shell, leaving the attached base. Their bodies become green as they feed on the leaves of the host plant. After the first molt the head is green with two narrow purplish lines extending down over each eye, but in later instars these lines disappear. Four light longitudinal dorsal lines appear on the body with the first molt and remain constant.

The mature larva (Fig. 10.) is light green closely approxinating the color of the underside of healthy cane leaves. On closer inspection the surface is seen to be marked with pale, chrome yellow, transverse lines near the intersections of the segments, and four, light, longi-

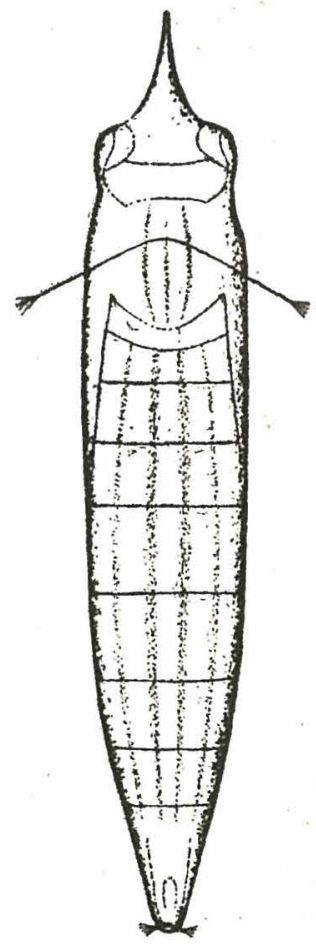

FIG. 11.-Chrysalis of Prenes nero Fabr. Enlarged 2 times. (Original.) tudinal, dorsal lines. All markings are more distinct at either end of the body. There are also numerous, very small, darker green dots and sparse short hairs. Below, the body is bluish green and laterally 
a white line extends along a slight fold just below the level of the stigmata.

The caterpillars, even while quite young, eat entirely through the leaf blade, beginning at the outer edge. During the day the larva rests in a shelter made by drawing together the edges of the leaf with a couple of silk bands, where it later pupates. One larva reared in the laboratory pupated after thirty days, having molted four or five times.

The chrysalis (Fig. 11.) rests on a film of silvery silk, its ventral surface next the leaf, and is held in place by a band of silk over the

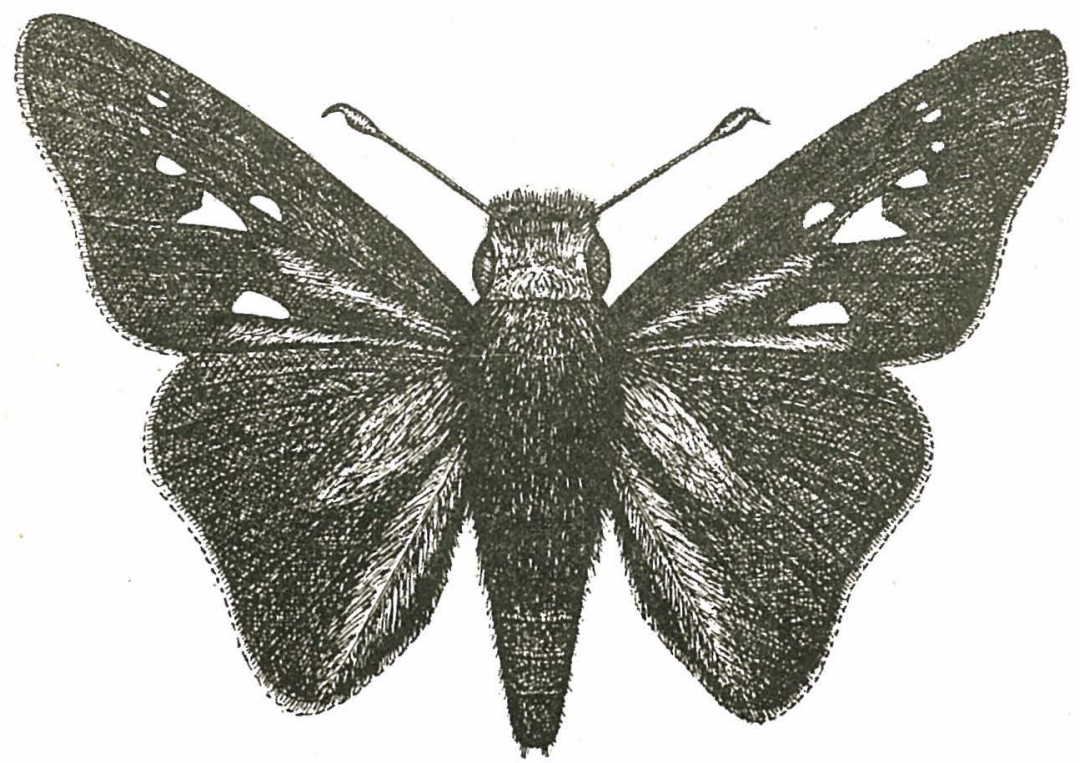

Fig. 12.-Adult of Prenes nero Fabr. Enlarged 2 times. (Originaī.)

thorax and by several strands at the anus. It is translucent, light green, with a number of slightly wavy light lines extending lengthwise dorsally. Four extend the full length of the thorax and abdomen, converging at either end, and one on each side, laterally, follows the line of tile stigmata. Ventrally, especially the wing-pads and undeveloped legs, and at either attenuated end, the pupa is more opalescent ard less green. On the head projects a curved, conical tubercle or horn. The pupa is about $30 \mathrm{~mm}$. long and 5 $\mathrm{mm}$. wide. A day or two before it issues, the eyes of the butterfly in the chrysalis become bright pink. Later the entire pupa becomes dark purplish. The pupal period required ten or twelve days in those individuals kept under observation. 
The adult (Fig. 12.) is a dark brown, thick-bodied butterfly, with wings darker above than below and the ventral surface of the body nearly white. Of the scven, or less, white, semi-transparent spots on each of the forewings, the largest is acutely triangular. The wing spread of the largest adults is $35 \mathrm{~mm}$.

The larvae of this skipper, the most abundant of any found in cane fields, are parasitized by two species of hymenopterous insects. The larvae of one Ardatus antillarum Gahan, issue from the caterpillars and form naked black pupae nearby, sixteen individuals having been observed to come from one large larva. The larvae of the other, Apantales prenidis Mues., spin white cocoons like grains of rice above the empty caterpillar skin. A female wasp, Polistes crinitus Felton, was observed to bite into and suck the juices from a pupa which she had discovered.

The most important enemy of the species in an egg parasite, Trichogramma minutum Riley; a minute, light-yellow wasp, adults of which issued from over two-thirds of the eggs of the butterfly found in the field. From seven to eleven individuals have been observed to emerge through a small hole in the side of an egg. This and the other parasites are so effective in keeping down the numbers of Prenes nero that artificial means of control need not be considered.

Prenes ares Felder.

The larvae of this skipper, which are even less abundant in cane fields than those of Prenes nero, have also been found on a number of other coarse-leaved grasses common in Porto Rico.

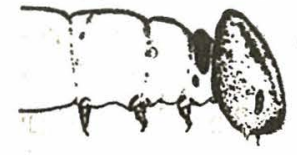

Fig. 13. - Lateral view of head and thorax of Prenes ares Felder. Enlarged 2 times. (Original.)

The hemispherical, lighigreen or yellow eggs are laid singly. The measure about 1.5 $\mathrm{mm}$. in diameter and are delicately reticulated; the reticulations near the apex being hexagonal and those towards the base linear. They hatch in three or four days, turning sil-

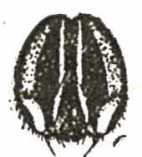

FIG. 14.-Cephalic view of head of larva of Prenes ares Felder. Enlarged 2 times. (Original.)

very grey just before hatching.

The young larva is transparent yellow, becoming light-green after feeding, with a large black head and with a black line, appearing from above like a collar, on the dorsal part of the first segment of the body and extending on either side to the spiracle. The caterpillar, as it emerges from the egg, is about $4 \mathrm{~mm}$. long and sparsely 
covered with stiff black hairs which disappear after the first molt. The fully grown larva is of a bluish grey green, with true legs black at tip and ringed with black, and a black collar on the dorsal posterior portion of the first segment, ending in lateral enlargements at the spiracles (Fig. 13.) The spiracles of this segment are black; the others are of the same color as the body and scarcely distinguishable. The head (Fig. 14.) is brown with median and lateral markings of yellow, sometimes covering a larger area than the brown portion. The largest larva observed was $38 \mathrm{~mm}$. long.

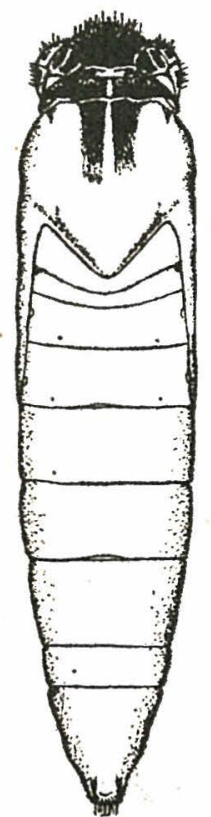

FIG. 15.-Chrysalis of Prenes ares Felder. Enlarged 2 times. (Original.)

The caterpillar feeds at night, eating the edges of the leaves, and rests during the day in a shelter made by pulling together two or three leaves at their tips and holding them in place with silk. In this shelter a thin cocoon of white silk is spun, in which the larva pupates.

The chrysalis (Fig. 15.) is light yellow, with creamy opalescent wingpads, and is covered with light yellow hairs. The head is specially hairy, dark-brown above, with brown crescents on the eyes. There are two large brown spots and several pairs of smaller ones on the thorax. The proboscis tube is free, extending to the middle of the 11th segment. The chrysalis is about $27 \mathrm{~mm}$. long. Adults have emerged on the ningth or tenth day after the pupa was formed.

- The adult is dark-brown, thick-bodied, butterfly, differing most markedly from that of Prenes nero by having the largest white spot on the forewings irregularly rectangular. Beneath, the wings are marked with light, bluish-white, irregular bands. The wing spread is about $35 \mathrm{~mm}$.

The eggs of Prenes ares are parasitized by Trichogramma minutum, thirty-two adults having emerged from one egg. There are at least two small Ichneumonid parasites of the larva, Apantales prenedis Mues., which is black and Microbracon sp. which is yellowish brown.

Atrytone vittelius Fabr.

The larva of this small skipper feeds on older cane leaves and has twice been quite common at Río Piedras.

The eggs are hemispherical, about $1.3 \mathrm{~mm}$. in diameter, grey be- 
low, darker towards the apex, and marked with hexagonal reticulations.

The larva when first hatched are light grey-green, so transparent that their internal organs are plainly visible, but becoming green and more opaque as they begin to feed. On the first segment there is a dorsal black band, terminating laterally just above a black dot, and the head is black, becoming lighter brown, lined with black, in the later instars. Fully grown caterpillars are $35 \mathrm{~mm}$. long. The general color of the body is robin's egg blue, but looked at more closely is seen to consist of a lighter-colored network surrounding numerous darker spots subtending small hairs. There is a darker medio-dorsal stripe, and the three anterior and the posterior segments are somewhat more yellow-green than blue. The spiracles are yellow, and the true legs are also opalescent light yellow. On the dorsal half of the first segment is a black half-ring ending on each side just above a large black spot. The head is roughly granular, dull yellow, black where attached to the neck, around the outer edge and in front in two broad straight vertical lines.

The larvae feed at night, resting by day in shelters of partlyeaten, folded-over leaves, held together with numerous strands of silk, in which, after filling in the open ends with more silken strands, the chrysalis is formed. The chrysalis is $18.5 \mathrm{~mm}$. long by $3.5 \mathrm{~mm}$. wide, opalescent creamy yellow on the wings, lighter on the abdomen, but a dull light red on the head, which also has many straight hairs, the rest of the pupa being faintly pubescent. The general appearance of the chrysalis is similar to that of Prenes ares, but smaller and unmarked.

The adult is a small butterfly, with brilliant, shining, chrome yellow wings, margined with black, having an expanse of about $27 \mathrm{~mm}$.

\section{Cirphis (Heliophila) latiuscula H. S.}

This is the least important of the noctuids whose larvae feed on cane leaves in Porto Rico, largely because the caterpillars feed on the leaves of large and mature cane and usually oceur singly. They usually feed on the edges of the leaves, and are found in the daytime resting far down in the central whorl of leaves. The eggs have not been found. The caterpillars, though of similar appearance, vary considerably in color. Many are light greenish grey, with numerous lines extending along the back and sides; the head being 
light brown and the spiracles black. Some are more yellowish and others browner, and others are somewhat pinkish, especially between the segments. All larvae have a smooth appearance, the smaller ones being generally lighter in color and more translucent. The fullgrown larvae are about $40 \mathrm{~mm}$. long.

The pupa is formed in a loosely constructed cocoon in old leafsheaths or in trash adhering to the stalk or on the ground. It is dark-reddish brown, smooth and polished, and about $19 \mathrm{~mm}$. long. The pupal period is from two to three weeks.

The cream-colored adults have a wing expanse of about $35 \mathrm{~mm}$. The body is cream colored, the forewings light grey and the hind

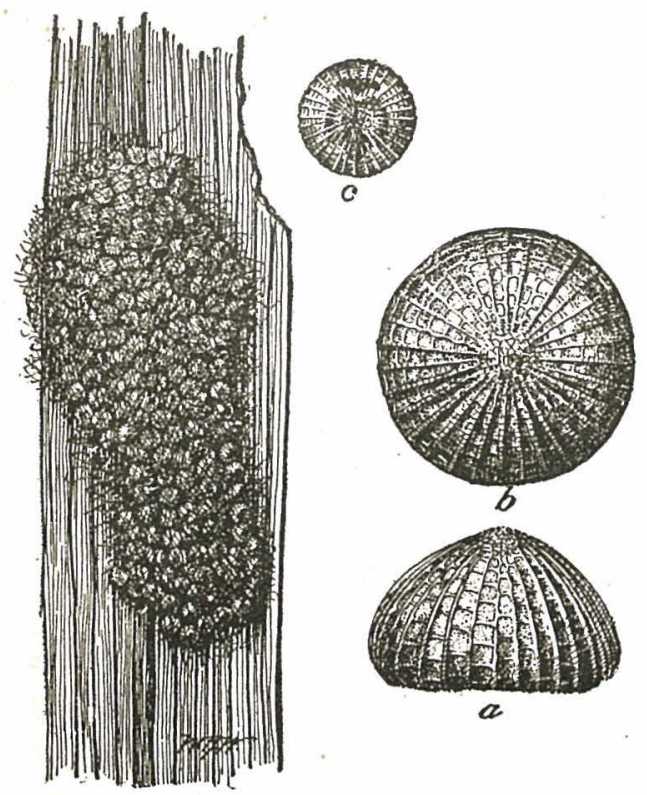

EIG. 16.-Eggs of Laphygma frugiperda S. \& A. Egg mass at left about twice natural size; $a$, highly magnified egg, side view; $b$, same from above; $c$, egg ready to hatch, larva showing thru the shell. (after Walton \& Luginbill.) wings glistening white, bordered with grey. The front wings are speckled with two rows of black points, one close to the outer margin, the other, of larger and more distinct points, less distal. There is also noticeable a bright spot near the middle of the forewings. Beneath, the wings and body are lighter than above.

There are numerous parasitic enemies of Cirphis latiuscula. The ubiquitous Trichogramma minutum is doubtless responsible for the destruction of many eggs. The larvae are parasitized by Apanteles marginiventris Cresson, and by an Euplectrus. The naked larvae of the Euplectrus feed on the outside of the caterpillar until they are fully grown and ready to pupate, when they crawl beneath the empty caterpillar skin and spin therr brown, oval cocoons. Tachinid flies, Compsilura oppugnator Walton, also attack the larvae. The caterpillars have never occurred in sufficient abundance to make the employment of artificial methods of control necessary. 


\section{Laphygma frugiperda S. \& A.}

Laphygma frugiperda is a well-known pest in all the Americas, especially in the United States, where it is known as the fall army worm or southern grassworm. It usually feeds on grasses or allied plants, but when occurring in enormous numbers and having destroyed its usual host plants it will attack almost any green vegetation. In Porto Rico it is a serious pest of corn and it is sometimes locally abundant on cane. Some caterpillars will usually be found in any pasture and in low pastures of malojillo grass, especially those subject to flooding, the grass may be entirely destroyed. Caterpillars are most abundant during the fall and winter months and at this season of the year constitute one of the principal enemies of young corn,

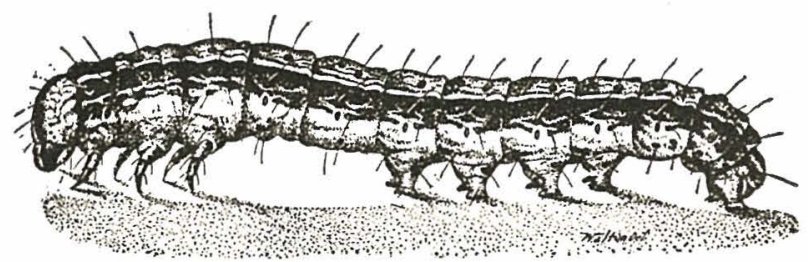

FIG. 17.-Larva of Laphygma frugiperda S. \& A. Enlarged 2 times. (after Walton \& Luginbill.)

while they may entirely defoliate young gran-cultura cane and, although not kjlling the plants, may set them back so that they never catch up with unattacked plants.

The eggs (Fig. 16.) are deposited in clusters, usually on plants on which the young caterpillars can feed, but sometimes on boards, posts, or stones in the field. The number of eggs in a clusters varies from less than 50 to more than 200 . When the clusters are large the eggs are placed in tiers, one layer above another. The female moth covers the eggs with a light grey, felty covering. The individual eggs are spherical, glistening pearly or greenish white, about $.5 \mathrm{~mm}$. in diameter, with minute vertical ribs. They hatch in thre or four days after deposition.

The caterpillars when they first issue from the eggs are about $1 \mathrm{~mm}$. long, grey, with a comparatively large black head. They feed together for a time, devouring the egg shells, and then disperse in search for other food. Even when very small they travel considerable dis-

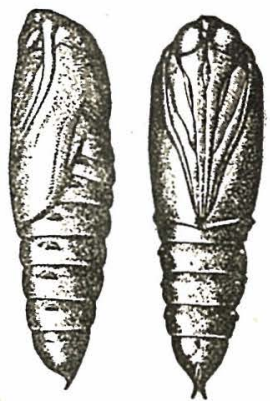

Fig. 18.-Pupa of Laphygma frugiperda S. \& A. (after Walton \& Luginbill.) tances and are aided in their progress by the wind. When the eggs have been placed on trees or fence posts the larvae suspend 
themselves in the air by a fine silken thread which, being broken by the wind, serves as a parachute to carry the little caterpillar to a considerable distance.

The young caterpillars at first feed only on tender foliage, usually chewing off the epidermis from one surface of a leaf, but later they devour entire leaves. Except when young, caterpillars kept in confinement attack one another and cannibalism occurs normally in the field when they are abundant, and is an important factor in reducing their numbers under such conditions. Larvae reared in the laboratory at Río Piedras in May became full grown in twenty-one days after hatching, moulting six or seven times. With each molt there is a change in coloration and an increase in size, the caterpillars being about $32 \mathrm{~mm}$. long when full grown. The general color of the large caterpillars (Fig. 17.) is olive green, with darker stripes laterally and more transparent and greener, from the food seen

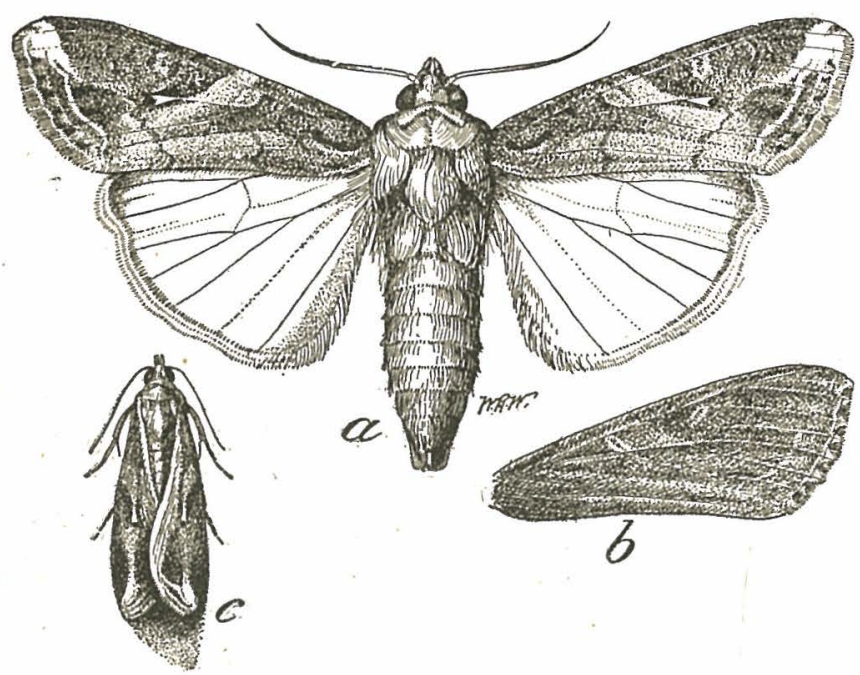

Fig. 19.-Adult of Laphygma frugiperda S. \& A: a, Male moth; $b$, right front wing of female moth, both about twice natural size; $c$, moth in resting position, natural size. (after Walton \& Luginbill.) within, beneath. On the dorsum of each of the abdominal seg. ments are four large dark spots which outline an isosceles trapezium. These spots and an inverted $Y$ of white, light grey, or light yellow, on the yellow-brown head are constant characters by which the larvae may be identified'.

The caterpillars feed mostly at night, except on dark days or when the food supply becomes nearly exhausted. They usually remain hidden during the day, on the ground at the base of their food plant, or on sugar cane and corn, in the central whorl of leaves. When their food supply in one place becomes exhausted they often 
start moving in large numbers, to which habit is due the common name of army worm.

When ready to pupate, the caterpillar burrows into the soil to a depth of about an inch, where its movements hollow out a little chamber scarcely larger than its body. The pupa (Fig. 18.) is about $15 \mathrm{~mm}$. long, glistening, dark reddish brown, rounded at the head end and pointed at the other. The pupal stage lasts from ten to twelve days.

The adult moths (Fig. 19.) show considerable variation in coloration and markings, most individuals being variants from two general types. In one type the upper surface of the forewings is greybrown, with markings indistinct or lacking; in the other the forewings are rather attractively marked with white, black, yellowbrown, red-brown, and pale blue. The hind wings are glistening white, bordered with grey-brown, both above and below. The body and underside of the forewings are light grey-brown, darker on the upper side of the thorax. The moths remain inactive and hidden during the day; the activities of flying, feeding, mating, and laying eggs being carried on at night.

The parasites and predators on Laphygma frugiperda are numerous in Porto Rico. Three tachinid flies, Frontina archippivora Will., Gonia grassicornis Fabr., and Archytas piliventris v. d. W., are possibly the most important in destroying the larvae. Their eggs are laid on the head or thorax of the larvae, into the bodies of which the young maggots bore. The maggots feed within the caterpillars and finally cause their death.

The female of Chelonus insularis Cress., after removing a portion of the covering of hairs from the egg cluster, lays its eggs in the eggs of the moth. Caterpillars from these eggs issue normally, but they contain the maggots of the wasp which kill them before they are more than half grown. The small caterpillars enter the soil as if to pupate, but soon die, and cocoons of the parasite will be found within the shriveled remains of the host eaterpillar.

Caterpillars are also killed by Apanteles marginiventris Cresson and two other parasites, common in Porto Rico, Trishogramma minutum Riley and Euplectrus comstockii Howard, have been recorded as parasites of it in the United States.

Two entomogenous fungi, Botrytis rileyi Farlow and Empusa sphaerosperma. Thaxter, attack the larvae; the fungous growth appearing externally after the caterpillars are dead.

A carabid beetle, Calosoma alternans Fabr., and an assassin bug, 
Zelus rubidus Lap. \& Serv., have been observed to kill caterpillars in the field. The blackbirds, mozambique or chango, and ani or judio, and lizards destroy many caterpillars and moths, and chickens and turkeys devour the caterpillars with avidity.

The injury done by the small larvae of Laphygma frugiperda is not especially noticeable, but when the caterpillars are more nearly full grown the amount of food they consume becomes so great that overnight the grass or cane may be entirely defoliated. Unfortunately, it is usually not until this time that the presence of the worms is noted, and, because of their being nearly mature, and the amount of damage of which they are capable being nearly complete, the beneficial results of control measures which may be employed are greatly reduced. Also, when the caterpillars have been abundant in a certain section another destructive brood of the worms does not often follow. This is because most of the caterpillars are usually destroyed by the tachinid flies, but they do not kill most of the caterpillars until they are full grown and have finished their injury to the crop. The poisoning of such parasitized caterpillars will result adversely, as its effect is to kill the beneficial parasites-the tachinid flies-in an immature stage inside the caterpillars, which if left unmolested would prevent another outbreak of the army worms.

A sharp lookout should be kept, therefore, for the presence of the small larvae and when they are observed to be present in numbers on young cane, the application of powdered arsenate of lead will kill them before the damage is done. The poison can be dusted on the plants undiluted or mixed with ashes. No expensive equipment for its application is necessary, as it can be sifted out of a burlap bag or shaken out of a can with nail-holes in the bottom. The modern mechanical dusters, however, avoid waste of the poison and get it on more thoroughly and evenly. A very little bit of poison dusted into the whorls of young corn plants will make a surprising difference in getting an even stand, as these caterpillars are always present and usually in considerable and destructive abundance in corn in Porto Rico.

As the caterpillars prefer to feed on grass, injury to cane and other cultivated crops often occurs in fields that have been allowed to become grassy. When the caterpillars are so abundant on grass that they defoliate it, or it is destroyed by cultivation, they then quite naturally begin feeding on the crop. For this reason cane 
fields, and low-lying land immediately surrounding them, should be kept as free of grass as possible.

\section{Remigia (Mocis) repanda Fabr.}

Although Remigia repanda has a wide distribution in the Americas, the only records of it as a pest of sugar cane are from Trinidad by F. W. Urich and from Demerara by G. E. Bodkin. In Porto Rico the caterpillars are often found with those of other species, especially Laphygma frugiperda and Prenes nero, and in such cases. can cause rather serious damage.

The eggs have not been observed in Porto Rico, but Bodkin reports that they are "considerably less than one-sixteenth of an inch in diameter, of a green color, and laid on the blades of the grasses."

The caterpillars are yellow grey, darker above and below, with numerous fine longitudinal stripes on the lighter sides, colored and marked so that when stretched out at rest they can be scarcely distinguished from a dead cane leaf. Dorsally, at the sutures between the fifth and sixth and the sixth and seventh segments, are large black and white spots, invisible when the caterpillar is straight, but exposed in sharp relief when it is looped up. The caterpillars lack the first two pairs of abdominal legs and progress by looping up their body rather than by crawling, and are called loopers or measuring worms. They are $35 \mathrm{~mm}$. long when full grown.

The pupa is dark reddish brown, with a lavender bloom, and is formed in a slight cocoon under the leaf-sheath or in trash. The moth is yellow-brown with the enormously developed hind legs of one sex covered with a dense mat of hair. The forewings are subequally divided into three areas by darker transverse lines, the more distal area being always sharply defined. There are numerou's darker curved and wavy lines in the median area, besides a row of spots in the distal area and a wavy line close to the margin. The hind wings are darker towards the margin, but more; or entirely, uniform in color underneath. The moths have a wing expanse of from 30 to $40 \mathrm{~mm}$.

The Tachinid flies, Phorocera claripennis Macq., Linnaemyia fulvicauda Walton and Helicobia helicis Towns., are the most important parasites of this insect, over nine-tenths of the caterpillars sometimes being killed by them. The black and yellow wasp Chalcis near robusta Cress, and a yellow Ichneumonid, Rogas n. sp., have also heen bred from large caterpillars or from the pupae. The Sarcophagid fly, Sarcophaga sternodontis Towns., has been reared from the 
larvae of both Remigia repanda and Laphygma frugiperda, and even from white grubs, Lachnosterna vandinei Smyth and $L$. portoricensis Smyth. Dr. Aldrich states that this is "a strictly parasitic species as far as known and is an abundant parasite in the West Indies."

Unless the eaterpillars are observed when they are still small and poison applied before they have done much injury, it does not appear desirable to attempt to poison them, as the parasites will usually prevent another outbreak in the same or nearby fields during the same season. Indeed, in one case observed, where an attempt to control by spraying with arsenate of lead was made, the delay of a day in getting the poison ready after the injury to the cane had been observed made its application come so late that only a few caterpillars were killed, most of them having already spun cocoons for pupation. From about twenty cocoons collected, not a single moth emerged, all having been parasitized, indicating that there would be no danger of another destructive outbreak of larvae that season, even though the poison had been ineffective in killing many of the caterpillars.

\section{SUMMARY.}

The caterpillars which feed on the leaves of sugar cane in Porto Rico are pests of rather minor importance, due largely to their normal natural control by parasites. Those which become butterflies have never been observed to be sufficiently abundant to eat the leaves of more than a few plants in a cane field, but two of those which become moths (Laphygma frugiperda and Remigia repanda) sometimes, especially in low places, become so numerous as to entirely defoliate considerable areas of young cane. If the caterpillars are observed while they are still small and before they have done much injury dusting with powdered arsenate of lead will kill them and be a profitable operation. The poison is comparatively cheap in first cost and in application and can be applied with inexpensive homemade apparatus. If the damage is not observed until the caterpillars are full grown, poisoning will not only be ineffective in preventing the damage they have caused, but may be harmful. Most of the caterpillars killed may contain the immature stages of beneficial parasites which, if allowed to live, would insure this and adjoining fields against injury from another generation of the eaterpillars that season. 